\title{
Meningkatkan Kemampuan Motorik Kasar melalui Pembelajaran Senam Fantasi pada Anak Kelompok Raudathul Atfal di Kendari
}

\author{
Hasmin $^{1}$, Erdiyanti ${ }^{2}$ \\ ${ }^{1}$ Institut Agama Islam Negeri Kendari \\ ${ }^{2}$ Institut Agama Islam Negeri Kendari, Indonesia. E-mail: erdiyantierdi@gmail.com
}

\begin{abstract}
Articel info
Abstract

\section{Artikel history:}

Received: 4 April 2020

Revised: 18 April 2019

Accepted: 18 April 2020

This study aims to determine whether fantasy gymnastics learning can improve gross motor skills of children in in early year class in Kendari. This is an action research. Each cycle consists of four stages, namely planning, implementing, observing, reflecting and evaluating. Research subjects were 13 children in group B Raudatul Atfal (early year class) of Aisyiyah Nurhaq Baruga, Kendari in the 2018/2019 academic year, and consisted of 6 boys and 7 girls. Data collection uses observation, documentation and assessment sheets. The results showed that fantasy gymnastic learning can improve children's gross motor skills. Shown by the assessment by using a star score * means not yet developed, star **means starting to develop, star ***means developing as expected, star **** means developing very well. The percentage of children's gross motor skills continues to increase from Pre Cycle $23.07 \%$ to $61.53 \%$, in the first cycle and $84.61 \%$ in the second cycle.
\end{abstract}

DOI:
Keywords: fantasy gymnastics learning, gross motoric skills

\section{Informasi Artikel}

Riwayat Artikel:

Diterima: 4 April 2020

Direvisi: 18 April 2020

Accepted: 18 April 2020
DOI:

\begin{abstract}
Abstrak
Penelitian ini bertujuan untuk mengetahui apakah pembelajaran senam fantasi dapat meningkatkan kemampuan motorik kasar pada siswa PAUD di Kendari. Jenis penelitian adalah penelitian tindakan kelas (Classroom action research). Setiap siklus terdiri dari empat tahap yaitu perencanaan, pelaksanaan, observasi, refleksi dan evaluasi. Subjek penelitian yaitu 13 anak kelompok B. II RA. Aisyiyah Nurhaq Baruga, Kendari tahun pelajaran 2018/2019, dan terdiri dari 6 anak laki-laki dan 7 anak perempuan. Pengumpulan data menggunakan lembar observasi, dokumentasi dan penilaian. Hasil penelitian menunjukkan bahwa pembelajaran senam fantasi dapat meningkatakan kemampuan motorik kasar anak. Di tunjukkan dengan penilain dengan mengunakan skor bintang * artinya belum berkembang, bintang ** artinya mulai berkembang, bintang *** artinya berkembang sesuai harapan, bintang **** artinya berkembang sangat baik. Persentase kemampuan motorik kasar anak terus meningkat dari Pra Siklus 23,07\% menjadi 61,53\%, pada siklus I dan $84,61 \%$ pada siklus II.
\end{abstract}

Kata Kunci: : Pembelajaran senam fantasi, Kemampuan Motorik kasar 


\section{PENDAHULUAN}

Pendidikan pada dasarnya merupakan proses untuk membantu manusia dalam mengembangkan potensi dirinya untuk menuju perubahan yang lebih baik. Sebagaimana tertuang dalam Undangundang Sistem Pendidikan Nasional Nomor 20 Tahun 2003 menyatakan bahwa: "Pendidikan adalah usaha sadar dan terencana untuk mewujudkan suasana belajar dan proses pembelajaran agar siswa secara aktif mengembangkan potensi dirinya untuk memiliki kekuatan spiritual keagamaan, pengendalian diri, kepribadian, kecerdasan, akhlak mulia, serta keterampilan yang diperlukan dirinya, masyarakat, bangsa dan Negara.” (UU RI No. 20 Tahun 2003, tentang sistem pendidikan, 2006 )

Dalam pasal 28 UU Sistem pendidikan Nasional No. 20 Tahun 2003 pasal 1 ayat 14 sebagaimana yang dikutip oleh Suyadi menyatakan bahwa :Pendidikan Anak Usia Dini adalah suatu upaya pembinaan yang ditujukan kepada anak sejak lahir sampai dengan usia 6 tahun yang dilakukan melalui pemberian rangsangan pendidikan untuk membantu pertumbuhan dan perkembangan jasmani dan rohani agar anak memiliki kesiapan dalam memasuki pendidikan lebih lanjut, Usia dini pada anak biasa disebut sebagai usia emas atau golden age. Masa-masa tersebut merupakan masa kritis dimana seorang anak membutuhkan rangsangan-rangsangan yang tepat untuk mencapai kematangan yang sempurna. . (UU RI No. 20 Tahun 2003, tentang sistem pendidikan, 2006).

Menurut Hibana (2013) gerakan-gerakan senam bertujuan untuk mengembangkan motorik kasar pada anak. Anak dapat mengamati gerakan-gerakan yang dilakukan teman-temannya atau yang sudah dilatihkan kepadanya, kemudian mengingat gerakan-gerakan motorik yang telah dilakukan untuk memperbaiki gerakannya. Sebelum mampu memadukan aktivitas motorik yang kompleks, anakanak juga harus memiliki keterampilan dasar terlebih dahulu dan mampu bergerak sesuai dengan kemampuan yang dimiliki. Pertumbuhan dan perkembangan anak sangatlah penting dalam mempengaruhi aktivitas sehari-hari mereka. Para orangtua pasti menginginkan tumbuh kembang setiap anak dapat berjalan dengan optimal dan tidak memiliki hambatan suatu apapun.

Salah satu cara dalam mengembangakan kemampuan motorik anak adalah kegiatan senam fantasi. Kegiatan ini tidak bersifat formal seperti kegiatan pembelajaran di dalam kelas lainnya. Aktivitas ini dapat dilakukan di luar ruangan, maupun di lapangan terbuka. Dengan menggunakan iringan musik, akan membuat anak lebih semangat dan antusias dalam mengikuti kegiatan. Dalam kegiatan senam fantasi ini, anak dapat belajar berkonsentrasi mendengarkan iringan musik yang ada dan belajar untuk mengkoordinasikan gerakan-gerakan senam yang akan dicontohkan oleh para pendidik. Kegiatan Senam Fantasi dapat membantu perkembangan kemampuan gerak lokomotor seperti berjalan, berlari, meloncat, melompat, skipping, berlari cepat, dan berjalan, sedangkan kemampuan gerak nonlokomotor seperti keseimbangan, memutarkan badan, berbalik arah, dan melipat badan.Kegiatan tersebut membantu anak-anak untuk dasar-dasar kecerdasan otak, keseimbangan, dan koordinasi, dan meningkat keiramaan kinestetik bagi anak, kerena anak-anak dapat mengekpresikan ide dan perasaan dapat bentuk berolahraga.

Berdasarkan pemaparan di atas, peneliti terdorong untuk melihat bagaimana peningkatan kemampuan motorik siswa PAUD melalui kegiatan senam fantasi.

\section{METODE}

Jenis penelitian ini adalah Penelitian Tindakan Kelas (PTK), Menurut Bogdan \& Biken sebagaimana yang dikutip oleh Kunandar menjelaskan bahwa: penelitian tindakan merupakan pengumpulan informasi yang sistematis yang dirancang untuk menghasilkan perubahan sosial. (Kunandar, 2013). Penelitian dilaksanakan di Ra. Aisyiyah Nurhaq Baruga pada. Alasan peneliti memilih penelitian Ra. Aisyiyah Nurhaq Baruga karena pertama,berdasarkan observasi awal dikatakan kemampuan motorik kasar anak masih rendah terlihat sikap perilaku anak antara lain, yang tidak tertarik dan kurang aktif dalam mengikuti senam dikarenakan senam yang di gunakan kurang bervariasi sehinga anak cepat merasa bosan, dan mengakibatkan anak tidak tertarik tentang pembelajaran motorik kasar.

Penelitian ini dilakukan mulai januari s/d maret 2019, Pada semester genap (semester II) tahun ajaran 2018/2019. Tindakan pembelajaran dilakukan melalui 2 siklus. Subjek penelitian dalam penelitian ini adalah ini adalah di Ra. Aisyiyah Nurhaq Baruga Yang berjumlah 13 anak yang terdiri dari 8 anak laki-laki dan 5 anak perempuan. 
Untuk lebih memudahkan dalam pemecahan masalah, ada beberapa hal yang akan diteliti anatara lain: senam fantasi bentuk meniru (meniru gerakan hewan,tanaman dan manusia berjalan keberbagai arah dengan cara (berjalan maju, mundur, dan berjinjit) melompat dengan satu atau dua kaki mengerakan kepala, tangan dan kaki sesuai irama musik, desain penelitian ini terdiri atas empat kegiatan yang dilakukan dalam siklus berulang. empat kegiatan utama yang ada pada setiap siklus, yaitu 1) perencanaan, 2) tindakan, 3) pengamatan, 4) refleksi. (arikunto, 2010).

Penilain, dalam memberi penilaian pada setiap indikator aspek pengamatan umtuk menilai kemampuan dan aktifitas anak dalam rangka meninkatkan kemampuan motorik kasar anak dalam kegiatan senam fantasi, peneliti mengacu pada pedoman pemberian penilaian sesuai dengan (Permendiknas No. 58 Tahun 2009) yaitu dengan memberikan simbol-simbol dapat dilihat pada tabel berikut :

Tabel 1. Pedoman Penilain Kemampuan Motorik Kasar Melalui Senam Fantasi

\begin{tabular}{|c|c|c|}
\hline Aspek Penilain & Keterangan & Nilai Konvesi \\
\hline $\begin{array}{c}\text { BB } \\
\text { [ Belum Berkembang] }\end{array}$ & $\begin{array}{l}\text { Apabila anak tidak dapat memenuhi } \\
\text { indikator yang telah di tetapkan dan } \\
\text { anak belum menampakkan } \\
\text { kemampuannya serta selalu } \\
\text { dibimbing oleh ibu guru }\end{array}$ & $0,01-1,49$ \\
\hline $\begin{array}{c}\text { MB } \\
\text { [Mulai Berkembang] }\end{array}$ & $\begin{array}{l}\text { Apabila anak dapat memenuhi } \\
\text { indikator ynag telah ditetapkan dan } \\
\text { telah mampu menunjukkan } \\
\text { kemampuannya namun lebih } \\
\text { banyak dibimbing oleh ibu guru }\end{array}$ & $1,50-2,49$ \\
\hline $\begin{array}{c}\text { BSH } \\
\text { [Berkembang Sesuai } \\
\text { Harapan] }\end{array}$ & $\begin{array}{l}\text { Apabila anak dapat memenuhi } \\
\text { indikator yang telah ditetapkan dan } \\
\text { mampu menunjukkan } \\
\text { kemampuannya, namun terkadang } \\
\text { masih membutuhkan batuan dari } \\
\text { ibu guru }\end{array}$ & $2,50-3,49$ \\
\hline $\begin{array}{c}\text { BSB } \\
\text { [Berkembang Sangat baik] }\end{array}$ & $\begin{array}{l}\text { Apabila Anak Mampu } \\
\text { menunjukkan kemampuannya } \\
\text { sesuai dengan indikator yang telah } \\
\text { ditetapkan tanpa bantuan dari ibu } \\
\text { guru }\end{array}$ & $3,50-4,00$ \\
\hline
\end{tabular}

\section{HASIL PENELITIAN}

Peneliti akan mencoba mendeskripsikan apa yang terjadi pada penelitian di pra siklus, siklus I dan siklus II, serta apa yang menghambat atau tidak tercapaiya peningkatan pada pra tindakan dan siklus I, serta mengapa tekhnik yang digunakan belum membuat anak didik mencapai nilai yang baik dalam hal ini kemampuan motorik kasar anak pada kelompok B. II RA. Aisyiyah Nurhaq Baruga. Dipembahasan ini juga akan membahas tentang apa yg menyebabkan anak didik mengalami peningkatan kemampuan motorik kasar anak pada siklus I dan Siklus II, serta tehnik yang digunakan oleh guru atau peneliti dalam penelitian dikelompok B.II.

Pada kondisi awal sebelum adanya tindakan dalam penelitian ini. Kemampuan motorik kasar anak masih terlihat rendah pada setiap aspek dengan presentase keberhasilan secara keseluruhan 23,07 $\%$ dan berada pada kriteria mulai berkembang sesuai harapan 3 orang anak, 6 orang anak mulai berkembang dan 4 orang anak belum berkembang dengan prsentase ketidak berhasilan $23,07 \%$. Hal ini dapat diamati pada table 2 . 
Tabel 2. Deskriptif Perhitungan Secara Klasikal Pada Tahap Kegiatan Pra Silkus

\begin{tabular}{lcc}
\hline \multicolumn{1}{c}{ Uraian } & $\begin{array}{c}\text { Frekwensi } \\
\text { (Jumlah Anak) }\end{array}$ & Presentase \\
\hline $\begin{array}{l}\text { Banyaknya anak didik yang memperoleh nilai BB } \\
\text { (Nilai Konversi 0,01-1,49) }\end{array}$ & 4 & $30,76 \%$ \\
$\begin{array}{l}\text { Banyaknya anak didik yang memperoleh nilai MB } \\
\text { (Nilai Konversi 1,50-2,49) }\end{array}$ & 6 & $46,15 \%$ \\
$\begin{array}{l}\text { Banyaknya anak didik yang memperoleh nilai BSH } \\
\text { (Nilai Konversi 2,50-3,49) }\end{array}$ & 3 & $23,07 \%$ \\
$\begin{array}{l}\text { Banyaknya anak didik yang memperoleh nilai BSH } \\
\text { (Nilai Konversi 3,50-4,00) }\end{array}$ & 0 & \\
Jumlah seluruh anak didik pada kelompok B.II RA. & 13 & \\
Aisyiyah Nurhaq Baruga (Subjek Penelitian) & 3 & $23,07 \%$ \\
$\begin{array}{l}\text { Persentasi keberhasilan secara klasikal (\%) yakni } \\
\text { banyakanya anak didik yang dianggap berhasil, atau } \\
\text { anak didik yang memperoleh nilai BSH + Anak didik } \\
\text { yang memperoleh nilai BSB (Nilai Konversi 2,50- } \\
\text { 4,00) }\end{array}$ & & \\
\hline
\end{tabular}

Tabel 3. Deskriptif Perhitungan Secara Klasikal Pada Tahap Kegiatan Silkus I

\begin{tabular}{lcc}
\hline \multicolumn{1}{c}{ Uraian } & $\begin{array}{c}\text { Frekwensi } \\
\text { (Jumlah Anak) }\end{array}$ & Presentase \\
\hline $\begin{array}{l}\text { Banyaknya anak didik yang memperoleh nilai BB } \\
\text { (Nilai Konversi 0,01-1,49) }\end{array}$ & 1 & $7,69 \%$ \\
$\begin{array}{l}\text { Banyaknya anak didik yang memperoleh nilai MB } \\
\text { (Nilai Konversi 1,50-2,49) }\end{array}$ & 3 & $23,07 \%$ \\
$\begin{array}{l}\text { Banyaknya anak didik yang memperoleh nilai BSH } \\
\text { (Nilai Konversi 2,50-3,49) }\end{array}$ & 7 & $53,84 \%$ \\
$\begin{array}{l}\text { Banaknya anak didik yang memperoleh nilai BSH } \\
\text { (Nilai Konversi 3,50-4,00) }\end{array}$ & 2 & $15,38 \%$ \\
$\begin{array}{l}\text { Jumlah seluruh anak didik pada kelompok B.II RA. } \\
\text { Aisyiyah Nurhaq Baruga (Subjek Penelitian) }\end{array}$ & 13 & $100 \%$ \\
$\begin{array}{l}\text { Persentasi keberhasilan secara klasikal (\%) yakni } \\
\text { banyakanya anak didik yang dianggap berhasil, atau } \\
\text { anak didik yang memperoleh nilai BSH + Anak didik } \\
\text { yang memperoleh nilai BSB (Nilai Konversi 2,50- } \\
\text { 4,00) }\end{array}$ & 8 & $69,23 \%$ \\
\hline
\end{tabular}

Setelah diadakan tindakan pada siklus I dengan mengunakan senam fantasi yaitu senam menanam jagung kemampuan motorik kasar anak meningkat 7 anak didik dari 13 orang anak atau $69,23 \%$, berada pada kriteria berkembang sesuai harapan dan 2 orang anak didik berkembang sangat baik atau 15,38\% dengan tingkat keberhasilan $69,23 \%$ namun belum mencapai hasil yang maksimal yaitu belum mencapai indikator keberhasilan yang telah ditentukan yaitu $75 \%$ hal ini disebabkan oleh senam yang digunakan belum dikenal oleh anak dan mereka belum bisa melakukan senam secara mandiri, maka penelitian ini dilanjutkan ke siklus II. 
Tabel 4. Deskriptif Perhitungan Secara Klasikal Pada Tahap Kegiatan Silkus II

\begin{tabular}{|c|c|c|}
\hline Uraian & $\begin{array}{c}\text { Frekwensi } \\
\text { (Jumlah Anak) }\end{array}$ & Presentase \\
\hline $\begin{array}{l}\text { Banyaknya anak didik yang memperoleh nilai BB } \\
\text { (Nilai Konversi } 0,01-1,49)\end{array}$ & & $0 \%$ \\
\hline $\begin{array}{l}\text { Banyaknya anak didik yang memperoleh nilai MB } \\
\text { (Nilai Konversi } 1,50-2,49 \text { ) }\end{array}$ & 2 & $15,38 \%$ \\
\hline $\begin{array}{l}\text { Banyaknya anak didik yang memperoleh nilai BSH } \\
\text { (Nilai Konversi } 2,50-3,49 \text { ) }\end{array}$ & 5 & $38,46 \%$ \\
\hline $\begin{array}{l}\text { Banaknya anak didik yang memperoleh nilai BSB } \\
\text { (Nilai Konversi 3,50-4,00) }\end{array}$ & 6 & $46,15 \%$ \\
\hline $\begin{array}{l}\text { Jumlah seluruh anak didik pada kelompok B.II RA. } \\
\text { Aisyiyah Nurhaq Baruga (Subjek Penelitian) }\end{array}$ & 13 & $100 \%$ \\
\hline $\begin{array}{l}\text { Persentasi keberhasilan secara klasikal (\%) yakni } \\
\text { banyakanya anak didik yang dianggap berhasil, atau } \\
\text { anak didik yang memperoleh nilai BSH + Anak didik } \\
\text { yang memperoleh nilai BSB (Nilai Konversi 2,50- } \\
4,00 \text { ) }\end{array}$ & 11 & $84,61 \%$ \\
\hline
\end{tabular}

Di setiap siklus yaitu siklus I dan siklus II senam fantasi yang digunakan diganti sesuai dengan tahap kemampuan anak dalam melakukan kegiatan senam yang disesuaikan disetiap indikator yang akan dicapai. Dalam melakukan senam anak tidak dapat dilakukan secara tergesa-gesa,tetapi harus secarah bertahap.

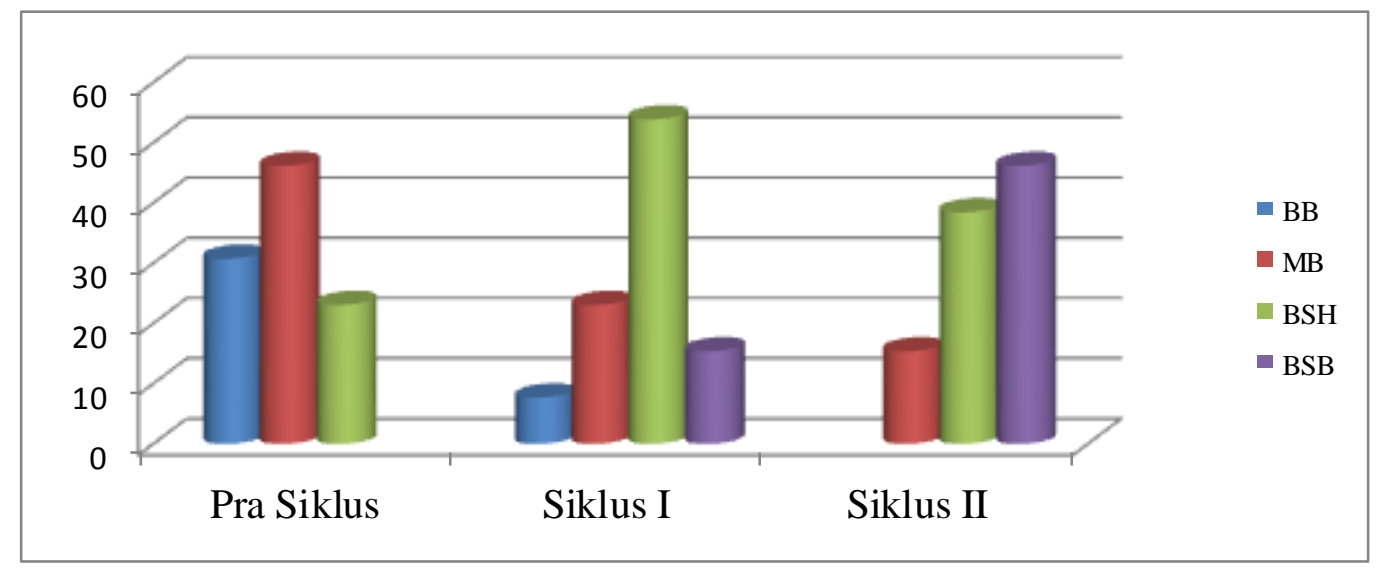

\section{Gambar. I. Grafik Perbandingan Hasil Observasi Pra Siklus, Siklus I Dan Siklus II}

Pada siklus II terjadi peningkatan persentase kemampuan motorik kasar yang sangat tinggi pada anak yaitu, 5 orang anak didik dari 13 orang anak didik atau 38,46\% berada pada kriteria berkembang sesuai harapan dan 6 orang anak didik berada pada kriterian berkembang sangat baik 46,15\%. Tingkat keberhasilan 84, 61\% dan telah mencapai kriteria ketuntasan minimal (KKM) yang ditetapkan yaitu $75 \%$. Hal ini telah menunjukkan bahwa anak telah mampu/dapat meningkatkan kemampuan motorik kasar anak. Dengan melakukan senam secara rutin diharapkan keterampilan motorik kasar anak dapat berkembang, terlihat keterampilan motorik kasar anak kelompok B di RA. Aisyiyah Nurhaq Baruga pada saat penelitian mencapai $23,07 \%$, pada siklus I mencapai $61,53 \%$ dan pada siklus II mencapai $84,61 \%$. Semakin rutin latihan keterampilan motorik kasar akan semakin baik. 


\section{PEMBAHASAN}

Perkembangan motorik adalah proses tumbuh kembang kemampuan gerak seorang anak. Pada dasarnya, perkembangan ini berkembang sejalan dengan kematangan saraf dan otot anak. Sehingga, setiap gerakan sesederhana apapun adalah merupakan hasil pola interaksi yang kompleks dari berbagai bagian dan sistem dalam tubuh yang dikontrol oleh otak.Menurut Sukintaka Perkembangan motorik merupakan perubahan tingkah laku motorik yang terjadi secara terus-menerus sepanjang siklus kehidupan manusia yang dipengaruhi oleh tuntutan-tuntutan tugas ,biologis individual dan juga lingkungan. Perkembangan diartikan sebagai satu perubahan individu pada tingkat fungsional. Sedangkan dalam domain psikomotorik, kognitif dan afektif, tingkat fungsional yang dimaksud adalah produk keturunan, kematangan, pertumbuhan, dan pengalaman sebagai pengaruh dari lingkungan.Secara konseptual, perkembangan anak didasarkan pada tiga domain yaitu psikomotorik, kognitif dan afektif. Domain psikomotorik terdiri atas kemampuan fisik dan motoriknya.Aktivitas fisik motorik yang rendah akan berdampak terhadap perkembangan kemampuan motorik anak. Guru perlu melakukan pendekatan, agar anak dapat aktif dan percaya diri terhadap gerakan, sehingga anak memiliki partisipasi yang lebih tinggi. Beberapa peneliti menemukan bahwa aktivitas fisik motorik sangat penting dalam mengembangkan keterampilan anak, dengan demikian anak harus aktif secara fisik untuk ,mengembangkan keterampilan motorik baru melalui gerakan motoric.

Dalam proses kegiatan senam fantasi yang digunakan harus diganti, sesuai dengan tahap kemampaun anak yang dari mudah ke yang rumit dan harus bertahap dan tidak tergesa-gesa, Kartini mengemukakan bahwa :pembelajaran pada anak harus berjalan secara teratur setingkat demi setingkat atau bertahap, hal ini sangat cocok dengan kodrat anak yang tumbuh dan berkembang secara bertahap. Dalam proses pembelajaran antara pendidik dan peserta didik harus ada interaksi. \{Kartini, 2012$\}$. Pendidikan pada dasarnya merupakan interaksi antara pendidik dengan peserta didik, untuk mencapai tujuan pendidikan, yang berlangsung dalam lingkungan tertentu, Agus Mahendra menyatakan bahwa senam sebagai suatu latihan tubuh yang dipilih dan dikonstruk dengan sengaja, dilakukan secara sadar dan terencana, disusun secara sistematis dengan tujuan meningkatkan kesegaran jasmani, mengembangkan keterampilan, dan menanamkan nilai-nilai mental spiritual. \{Agus Mahendra, 2015\} Menurut Sujiono ada delapan aspek penilaian motorik kasar anak yaitu kekuatan, daya tahan, kecepatan, kelincahan, kelentukan, koordinasi, ketepatan, dan keseimbangan. \{ Sujiono, 2016$\}$ guru di taman kanak-kanak lebih kreatif dalam memberikan pelajaran jasmani baik dalam pemberian metode yang tepat yaitu dengan cara memperhatikan prinsip dan aspek-aspek perkembangan fisik anak usia RA, serta harus dapat menyajikan kegiatan jasmani dengan baik yaitu memberikan contoh gerakan yang baik. Delphie mengemukakan bahwa dalam kehidupan di dunia ini ternyata hubungan antara manusia dengan irama, begitu pula dengan musik terdapat suatu bentuk yang saling tarik menarik sehingga menimbulkan ketegangan-ketegangan yang menjadikan tantangan bagi manusia itu sendiri untuk dapat melakukan.

\section{KESIMPULAN}

Berdasarkan hasil penelitian ini terdapat kesimpulan yakni, ada perbedaan perkembangan fisik motorik kasar anak kelompok B. II RA. Aisyiyah Nurhaq sebelum dan sesudah diberikannya aktivitas bermain senam fantasi. Berdasarkan perbedaan tersebut dilatarbelakangi oleh proses bermain senam fantasi yang lebih banyak melibatkan anggota gerak dengan menggunakan otot-otot besar, jika dibandingkan dengan aktivitas bermain sebelumnya. Selanjutnya kesimpulan kedua yakni adanya pengaruh aktivitas bermain senam fantasi terhadap perkembangan fisik motorik kasar anak usia 5-6 tahun pada RA. Aisyiyah Nurhaq. Adapun penerapan aktivitas bermain senam fantasi ini mempengaruhi indikator perkembangan fisik motorik kasar pada anak usia 5-6 tahun. Penggunaan aktivitas bermain senam fantasi memberikan kebebasan bagi anak untuk mengekpresikan gerak tubuh sesuai dengan imajinasi anak, sehingga memotivasi anak untuk melakukan kegiatan pembeajaran motorik kasar dengan penuh semangat. 


\section{DAFTAR PUSTAKA}

Agus Mahendra. (2015), Bermain Melalui Gerak dan Lagu Di TK. Jakarta: Depdiknas, Fadlillah Muhammad.(2016). Desain Pembelajaran Paud Yogyakarta : Ar-Ruzz Media, Hurlock. (2015). Model Pengembangan Ketrampilan Motorik Anak Usia Dini. Jakarta. Depdiknas Ike Ayu Sukmaningrum, Mengembangkan Ketrampilan Fisik Motorik Halus Anak Melalui Kegiatan Menjahit Untuk Usia 5 - 6 Tahun Semester I Tk Karangrejo 03 Kecamatan Wungu Kabupaten Madiun (Online), http://jurnal.fkip.uns.ac.id, diunduh 22 Maret 2016

Kunandar.(2013). Psikologi Perkembangan, Kendari: CV.Shadra

Martini. 2012. Peningkatan kemampuan motorik kasar anak melalui senam fantasi di TK Al-Hikmah Lubuk Basung.Jurnal pesona PAUD Volume 1 No 1. Tersedia di http://id.portal garuda.org/?ref=browse \&mod=viewarticle $\&$ article $=100804$. Di akses pada 26 Mei 2018

MS. Sumantri.(2015). Model Pengembangan Ketrampilan Motorik Anak Usia Dini, Jakarta: Departemen Pendidikan Nasional,

Rini. (2011). Psikologi Perkembangan Anak. Jakarta: Universitas Terbuka,

Rita Eka Izzaty.(2015). Mengenali Permasalahan Perkembangan Anak Usia TK, Jakarta : Departemen Pendidikan Nasional,

Samsudin. (2010) . Pembelajaran Motorik di Taman Kanak-Kanak. Prenada Media Grup:Jakarta

Sujiono. (2016). Metode Pengembangan Fisik, Jakarta: Universitas Terbuka

Yusmarni. 2012. Peningkatan kemampuan motorik kasar anak melalui senam fantasi menurut cerita di
TK
Negeri Pembina
Padang
Pariaman.Jurna
Pesona
PAUD

Vol.1No.1.Tersediadihttp://id.portalgaruda.org/index.php?ref=browse\&mod=viewarticle\& article $=100793 \mathrm{di}$ akses pada 26 Mei 2018 . 